\title{
Molecular characterization of isoniazid-resistant clinical isolates of Mycobacterium tuberculosis from the USA
}

\author{
Hongling Guo, ${ }^{1}$ Qihui Seet, ${ }^{1}$ Steven Denkin, ${ }^{1}$ Linda Parsons ${ }^{2}$ \\ and Ying Zhang ${ }^{1}$
}

Correspondence

Ying Zhang

yzhang@jhsph.edu

Received 11 May 2006

Accepted 3 August 2006

\begin{abstract}
${ }^{1}$ Department of Molecular Microbiology and Immunology, Bloomberg School of Public Health, Johns Hopkins University, 615 N. Wolfe Street, Baltimore, MD 21205, USA

${ }^{2}$ Clinical Mycobacteriology Laboratory, Wadsworth Center, New York State Department of Health, Albany, NY 12208, USA
\end{abstract}

\begin{abstract}
Drug-resistant tuberculosis poses a significant problem for treatment. The mechanisms of resistance to the front-line drug isoniazid $(\mathrm{INH})$ are complex and can be mediated by katG, inhA and other unknown genes. To identify the percentage of INH-resistant strains with no katG or inhA mutation, this study characterized a panel of 28 clinical isolates of Mycobacterium tuberculosis and five mutants derived from H37Rv resistant to INH. Seventeen of 33 resistant strains (51\%) had kat $G$ mutations with 12 of the 17 strains having the most common KatG Ser315Thr mutation. Three of the 17 strains with the KatG 315 mutation had an additional mutation in the inhA promoter and were resistant to a high level of INH. Seventeen of the $33 \mathrm{INH}$-resistant strains (51\%) had inhA mutations. The most common inhA promoter mutation was $-15 \mathrm{C} \rightarrow \mathrm{T}$ and was present in 13 of the 17 inh $A$ mutations. This promoter mutation occurred alone without kat $G$ mutations and was associated with a low level of INH and ethionamide resistance. However, other inhA mutations were associated with katG mutations. No mutations were found in the $n d h$ gene. Three of 33 strains (9\%) had no mutations in $k a t G$, inh $A$ or $n d h$, indicating that their resistance was due to a new mechanism of resistance. Detection of the KatG Ser315Thr mutation and the $-15 \mathrm{C} \rightarrow \mathrm{T}$ inhA mutation accounted for $76 \%$ (25/33) of the INH-resistant strains and should be useful for rapid detection of $\mathrm{INH}-$ resistant strains by molecular tests.
\end{abstract}

\section{INTRODUCTION}

The increasing problem of drug-resistant, especially multidrug-resistant, strains of Mycobacterium tuberculosis poses a significant threat to effective disease control in some parts of the world (Raviglione, 2003). Thus, there has been a great deal of interest in understanding the molecular mechanisms of drug resistance in this organism. Significant progress has been made in this area (Zhang et al., 2005). Understanding the mechanisms of drug resistance in M. tuberculosis will facilitate the rapid molecular detection of drug-resistant strains and provide useful clinical guidance for appropriate treatment of the disease.

Isoniazid (INH) is an important first-line tuberculosis drug. M. tuberculosis is highly susceptible to INH, with an MIC of $0 \cdot 03-0 \cdot 06 \mu \mathrm{g} \mathrm{ml}^{-1}$ (Zhang, 2004). INH is a pro-drug that requires activation by the $M$. tuberculosis catalase-peroxidase enzyme (KatG) to its active form (Zhang et al., 1992). Following activation, reactive radicals including isonicotinic acyl radical, isonicotinic acyl species (Rozwarski et al., 1998;

Abbreviations: ETH, ethionamide; $\mathrm{INH}$, isoniazid.
Broussy et al., 2003) and reactive oxygen species (Shoeb et al., 1985) can damage multiple targets in the cell (Zhang et al., 2005). One of these targets is InhA, an NADHdependent enoyl acyl carrier protein reductase involved in cell wall mycolic acid synthesis (Banerjee et al., 1994).

Resistance to INH is mediated by at least two genes in $M$. tuberculosis, katG (Zhang et al., 1992) and inhA (Banerjee et al., 1994). Mutation of the $k a t G$ gene, which leads to loss of or reduced catalase-peroxidase activity, is a major mechanism of INH resistance in M. tuberculosis (Heym et al., 1995; Musser et al., 1996; Zhang et al., 2005). Although various mutations in the $k a t G$ gene have been reported in INH-resistant isolates, the most common mutation is the KatG Ser315Thr mutation, which is present in approximately $50-90 \%$ of all INH-resistant isolates and is associated with relatively high-level resistance to INH (Zhang et al., 2005). Mutations in inhA or its promoter region can cause INH resistance, with promoter mutations being more frequent than mutations in the structural gene (Musser et al., 1996). Mutations in InhA cause not only INH resistance, but also resistance to the structurally related second-line drug ethionamide (ETH) (Banerjee et al., 1994). 
Although mutations in kas $A$ encoding a $\beta$-keto-acyl-acyl carrier protein synthase involved in mycolic acid synthesis were initially found in INH-resistant strains (Mdluli et al., 1998), subsequent studies found that kasA mutations were also detected in INH-susceptible strains (Lee et al., 1999; Ramaswamy et al., 2003). Mutations in $n d h$, encoding type II NADH dehydrogenase (Miesel et al., 1998), which increases the NADH/NAD ratio and competes for the binding of activated INH (isonicotinic acyl radical) to the target InhA (Miesel et al., 1998; Vilchèze et al., 2005), have been found in some INH-resistant clinical isolates in only one study (Lee et al., 2001). Mutations in the promoter region of $a h p C$, encoding alkyl hydroperoxide reductase, can compensate for loss of KatG in catalase-negative, INHresistant strains (Sherman et al., 1996; Wilson \& Collins, 1996). However, overexpression of AphC does not appear to confer significant INH resistance and $a h p C$ mutations may serve as a marker for INH resistance (Telenti et al., 1997). Despite these advances, some INH-resistant strains, especially those with low- to intermediate-level resistance with positive catalase activity, do not have mutations in any of the above genes involved in INH resistance (Zhang et al., 2005), suggesting a new mechanism(s) of INH resistance. In this study, we performed a detailed characterization of a panel of primarily INH-resistant $M$. tuberculosis strains in terms of their mechanism of INH resistance in order to shed light on the frequency of such strains.

\section{METHODS}

Mycobacterial growth. M. tuberculosis strains were grown in 7H9 liquid medium (Difco) supplemented with $0.05 \%$ Tween 80 and $10 \%$ bovine serum albumin/glucose/catalase enrichment (Difco) at $37^{\circ} \mathrm{C}$ for approximately $2-3$ weeks with occasional agitation.

Mycobacterial strains and drug-susceptibility testing. INHresistant $M$. tuberculosis clinical isolates were obtained from New
York State Department of Health, Albany, NY, USA. Strains R3, R8, $\mathrm{R} 9, \mathrm{R} 10$ and R11 were derived from M. tuberculosis H37Rv during in vivo treatment with INH in mice. The INH-resistant $M$. tuberculosis strains were identified by the BACTEC 460 radiometric method with an INH concentration of $0 \cdot 1 \mu \mathrm{g} \mathrm{ml}^{-1}$ as the cut-off for resistance (Siddiqi, 1992). To determine the MICs of INH and ETH for the INH-resistant strains, the agar proportion method was performed in $7 \mathrm{H} 11$ plates containing varying concentrations of INH $\left(0 \cdot 2,0 \cdot 4,1\right.$ and $\left.5 \mu \mathrm{g} \mathrm{ml}^{-1}\right)$ or ETH $\left(5 \mu \mathrm{g} \mathrm{ml}^{-1}\right)$.

Catalase activity assay. Catalase activity was assayed using a mixture of hydrogen peroxide (15\%) and Tween $80(10 \%)$ as described previously (Zhang et al., 1993). M. tuberculosis H37Rv was included as a susceptible control strain in the drug-susceptibility testing and also as a positive control for the catalase assay.

Bacterial genomic DNA isolation, PCR and DNA sequencing. Genomic DNA was isolated as described previously (Zhang et al., 1992). Oligonucleotide primers (Table 1) were designed from the $M$. tuberculosis $\mathrm{H} 37 \mathrm{Rv}$ genome sequence (Cole et al., 1998). The $2 \cdot 2 \mathrm{~kb}$ $k a t G$ gene $(\operatorname{Rv} 1908 \mathrm{c})$, a $1.5 \mathrm{~kb}$ region of the mabA-inhA gene (Rv1843-Rv1484) and the $1.4 \mathrm{~kb} n d h$ gene $(\operatorname{Rv} 1854 \mathrm{c})$ were amplified by PCR. The standard PCR mixture $(50 \mu \mathrm{l})$ contained $1.5 \mathrm{U}$ HotStarTaq DNA polymerase, $1 \times$ the recommended buffer supplemented with $1.5 \mathrm{mM} \mathrm{MgCl}_{2}$ (Qiagen), $500 \mathrm{nM}$ each forward and reverse primer, $200 \mu \mathrm{M}$ each dATP, dGTP, dCTP and dTTP and $1 \mu$ DNA template $(\sim 0 \cdot 1 \mu \mathrm{g})$. PCR was performed using a Hybaid Omni-E PCR thermocycler with the following cycle conditions: initial denaturation at $95^{\circ} \mathrm{C}$ for $10 \mathrm{~min}$, followed by 40 cycles of $94{ }^{\circ} \mathrm{C}$ for $40 \mathrm{~s}, 55^{\circ} \mathrm{C}$ for $40 \mathrm{~s}$ and $72^{\circ} \mathrm{C}$ for $120 \mathrm{~s}$, with a final extension at $72{ }^{\circ} \mathrm{C}$ for $10 \mathrm{~min}$. PCR products were detected by $0.8 \%$ agarose gel electrophoresis, followed by UV detection after ethidium bromide staining. To determine the $k a t G$, inhA and mabA-inhA promoter and $n d h$ sequences, PCR products containing these genes were purified from the agarose gel after electrophoresis using a gelpurification kit (Qiagen) according to the manufacturer's instructions. PCR products were sequenced directly using an ABI 377 automatic DNA sequencer (Applied Biosystems) using appropriate primers for amplifying the INH resistance genes or internal sequencing primers (Table 1).

Table 1. Oligonucleotide primers used in PCR and DNA sequencing

\begin{tabular}{|lll|}
\hline INH resistance gene & Primer & \multicolumn{1}{c|}{ Sequence $\left(\mathbf{5}^{\prime} \rightarrow \mathbf{3}^{\prime}\right)$} \\
\hline$k a t G$ & $k a t G-\mathrm{F}$ & TCCTGTTGGACGAGGCGGAG \\
& $k a t G-\mathrm{R}$ & CCGTCTCGTCATCCCCGTCT \\
& $k a t G-\mathrm{S} 1$ & TGGGAGCCCGATGAGGTCTA \\
& $k a t G-\mathrm{S} 2$ & AGATCCTGTACGGCTACGAG \\
& $k a t G-\mathrm{S} 3$ & GGCGAAGCCGAGATTGCCAG \\
& $k a t G-\mathrm{S} 4$ & ACAGCCACCGAGCACGAC \\
& $k a t G-\mathrm{S} 5$ & GTCCCGTCATCTGCTGGCGA \\
& $k a t G-\mathrm{S} 6$ & CCATGGGTCTTACCGAAAGT \\
& $i n h A-\mathrm{F}$ & TCGTAGGGCGTCAATACACCGCA \\
& $i n h A-\mathrm{R}$ & CGTCCAGCAGTCCTGTCATGTGCGT \\
& $n d h-\mathrm{F}$ & ATTCACCGACGCCATCGACG \\
& $n d h-\mathrm{R}$ & ATGACACATGTCCTCAACTGG \\
& $n d h-2 \mathrm{~F}$ & TACTGGAATGGCTCACGCTC \\
& $n d h-3 \mathrm{~F}$ & CGCTGACCGAGCTTTGCGCC \\
& $n d h-4 \mathrm{~F}$ & AGGTCGATGTGGGTGACGTT \\
& \\
\hline
\end{tabular}




\section{RESULTS AND DISCUSSION}

Twenty-nine clinical isolates of $M$. tuberculosis resistant to $0 \cdot 1 \mu \mathrm{g} \mathrm{INH} \mathrm{ml}{ }^{-1}$ were subjected to MIC determination by the 7H11 agar method as described in Methods (Table 2). Strain 2 was contaminated and was therefore discarded. The remaining 28 clinical isolates and five INH-resistant laboratory mutants derived from INH monotherapy of $M$. tuberculosis $\mathrm{H} 37 \mathrm{Rv}$ infection in mice were analysed for their level of INH resistance, catalase activity and mutations in the genes associated with INH resistance. The level of INH resistance ranged from $0 \cdot 2$ to $5 \mu \mathrm{g} \mathrm{ml}^{-1}$, with the majority of strains being resistant to $0 \cdot 2-1 \mu \mathrm{g} \mathrm{INH} \mathrm{ml}{ }^{-1}$ (Table 2). Most of the strains were catalase-positive with low to intermediate levels of resistance. Four strains (strains 8, 27 and 28 and $\mathrm{H} 37 \mathrm{Rv}$ mutant R9) had little or no catalase activity, with intermediate to high levels of resistance (1-5 $\mu \mathrm{g} \mathrm{ml}^{-1}$ ). Overall, the findings confirmed the previous observation that low- to intermediate-level resistant strains can be catalase-positive, whereas high-level resistant strains are often catalase-negative (Middlebrook, 1954; Zhang, 2004).

Sequence analysis revealed that 17 of the 33 strains (51\%) had kat $G$ mutations. Twelve of these 17 strains (strains 3, 5, 7, 9, 17, 18, 23, 26 and 29 and H37Rv mutants R8, R10 and R11) had the most common KatG Ser315Thr mutation, which retains catalase-peroxidase activity but causes reduced binding of INH to KatG (Wengenack et al., 1998; Yu et al., 2003). Strain 29, in addition to having the KatG Ser315Thr mutation, also had the KatG 463 polymorphism, which is not associated with INH resistance (Heym et al., 1995). Strains with the KatG Ser315Thr mutation alone had MICs of $\sim 1 \mu \mathrm{g} \mathrm{INH} \mathrm{ml}{ }^{-1}$. However, strains 3, 5 and 18, with mutations in the inhA promoter in addition to the KatG 315 mutation, were resistant to high levels of INH $\left(5 \mu \mathrm{g} \mathrm{ml}^{-1}\right.$ ) (Table 2). Seventeen of the $33 \mathrm{INH}$-resistant strains $(51 \%)$ had inhA promoter or structural gene mutations (Table 2). The most common inhA promoter mutation was $-15 \mathrm{C} \rightarrow \mathrm{T}$ (Ramaswamy et al., 2003; Madison

Table 2. Characteristics of INH-resistant clinical isolates of $M$. tuberculosis

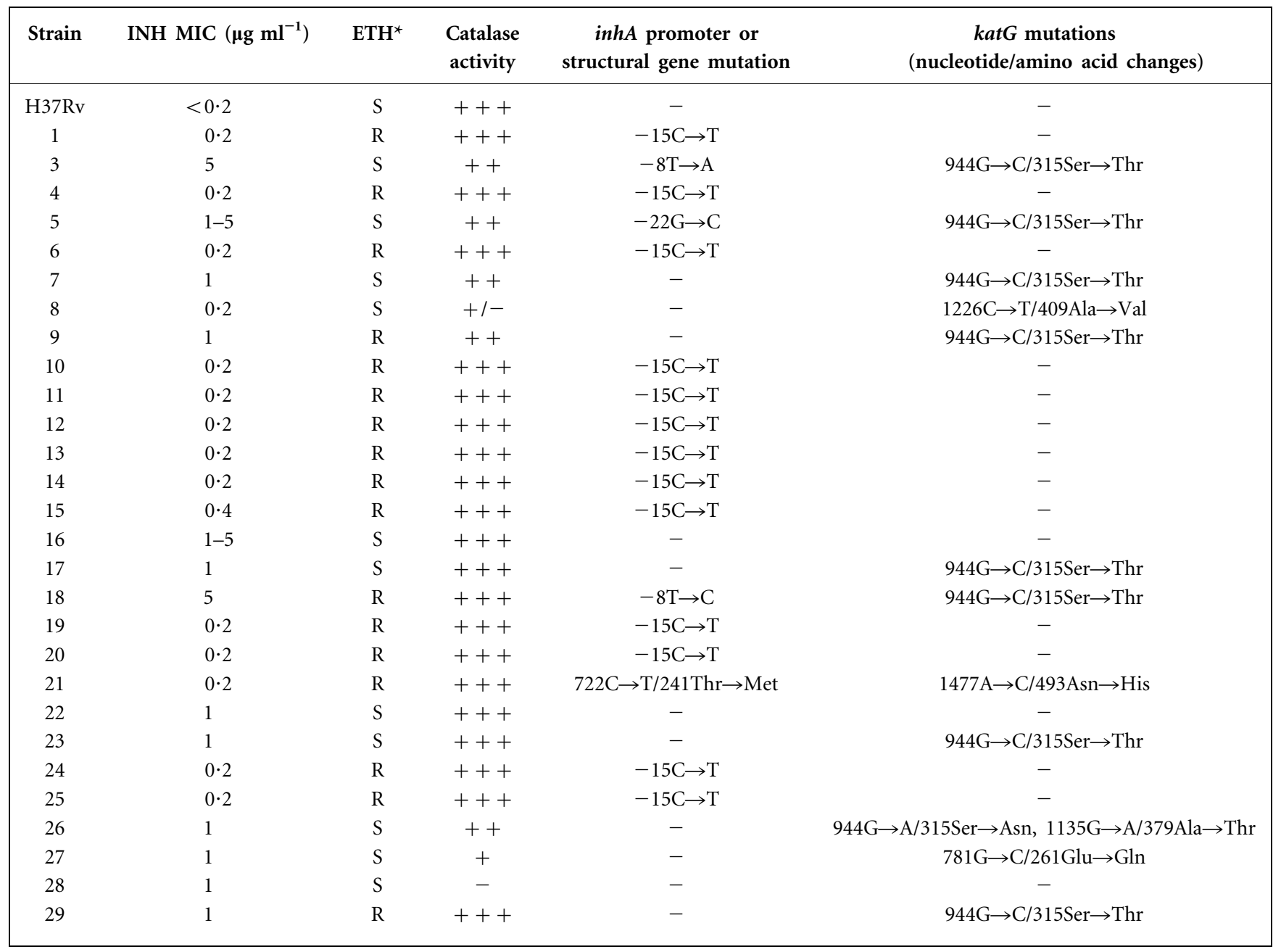

${ }^{\star}$ S, Sensitive; R, resistant (growth at $5 \mu \mathrm{g} \mathrm{ETH} \mathrm{ml}^{-1}$ ). 
et al., 2004), which was present in 13 of the 17 inhA mutations. It is interesting to note that all 13 strains with the $-15 \mathrm{C} \rightarrow \mathrm{T}$ mutation were resistant to a low level of INH $\left(0 \cdot 2 \mu \mathrm{g} \mathrm{ml}^{-1}\right)$ and did not have mutations in kat $G$ or $n d h$. In contrast, of the remaining four strains with inhA mutations (strains 3, 5, 18 and 21), three had inhA promoter mutations $(-8 \mathrm{~T} \rightarrow \mathrm{A},-8 \mathrm{~T} \rightarrow \mathrm{C}$ and $-22 \mathrm{G} \rightarrow \mathrm{C})$ and one had an inhA structural gene mutation of Thr241Met, which is a new mutation. These four strains also had mutations in $\mathrm{kat} G$ in addition to inhA mutations (Table 2) and three of them (strains 3, 5 and 18) had the same KatG Ser315Thr mutation and were more resistant to INH $\left(5 \mu \mathrm{g} \mathrm{ml}{ }^{-1}\right)$. However, strain 21, which contained inhA Thr241Met and katG Asn493His, had a low MIC of $0 \cdot 2 \mathrm{INH} \mu \mathrm{g} \mathrm{ml}{ }^{-1}$. These findings suggest that: (i) $-15 \mathrm{C} \rightarrow \mathrm{T}$ can be present by itself and is associated with a low level of INH resistance; (ii) inhA promoter mutations (e.g. $-8 \mathrm{~T} \rightarrow \mathrm{A},-8 \mathrm{~T} \rightarrow \mathrm{C}$ ) can occur with katG mutations (KatG Ser315Thr) to confer a higher level of INH resistance; and (iii) mutation of the inhA structural gene is associated with a low level of resistance.

As inhA mutations also confer co-resistance to INH and ETH (Banerjee et al., 1994), we examined the ETH susceptibility of the INH-resistant strains. Seventeen of the 33 strains were co-resistant to ETH, with all 13 strains with the inhA $-15 \mathrm{C} \rightarrow \mathrm{T}$ mutation being resistant to both ETH and INH. Strains 18 and 21 with the $-8 \mathrm{~T} \rightarrow \mathrm{C}$ and Thr241Met inhA mutations, respectively, were also resistant to ETH. However, strains 3 and 5 with $-8 \mathrm{~T} \rightarrow \mathrm{A}$ and $-22 \mathrm{G} \rightarrow \mathrm{C}$ inhA promoter mutations, respectively, were susceptible to ETH (Table 2). The inhA $-15 \mathrm{C} \rightarrow \mathrm{T}$ mutation is one of the most commonly reported inhA mutations (Bakonyte et al., 2003; Morlock et al., 2003; Sajduda et al., 2004) and presumably causes overexpression of InhA, the target of INH and ETH, thus resulting in co-resistance to both INH and ETH. Strains 9 and 29 were resistant to ETH but did not contain inhA or $n d h$ mutations, and this could be due to mutations in etaA/ethA involved in ETH activation (Baulard et al., 2000; DeBarber et al., 2000). Further studies are needed to address the basis for mechanisms of ETH susceptibility in strains 3 and 5 with inhA mutations and also the ETH resistance in strains 9 and 29 without inhA mutations.

Mutation of $n d h$, which causes an increase in the NADH/ NAD ratio, has been found to cause INH resistance in Mycobacterium smegmatis (Miesel et al., 1998) and Mycobacterium bovis BCG (Vilchèze et al., 2005), but not in $M$. tuberculosis, presumably because of the different role that Ndh plays in M. bovis compared with M. tuberculosis (Vilchèze et al., 2005). So far, only one study has reported $n d h$ mutations in some INH-resistant clinical isolates (Lee et al., 2001), but unfortunately these strains were discarded and are not available for analysis of the stability of the $n d h$ mutations. It is interesting to note that, in this study, of 33 INH-resistant strains, only one, strain 13, which had the $-15 \mathrm{C} \rightarrow \mathrm{T}$ mutation in the inhA promoter, was initially found to harbour multiple mutations in the $n d h$ gene.
However, upon subculture in liquid medium without $\mathrm{INH}$, strain 13 lost its $n d h$ mutations. It is likely that strain 13 is composed of mixed bacterial populations of sensitive and resistant clones and that the clones harbouring mutations in $n d h$ may be at a disadvantage and are therefore selected against during culture in vitro, although the clones with ndh mutations may survive in vivo and be detected initially when first isolated from clinical specimens.

Three (strains 16, 22 and 28) of the 33 strains (9\%) had no mutations in $k a t G$, inhA or $n d h$. Strains 16 and 22 were catalase-positive and their resistance could be due to a new mechanism of INH resistance. In contrast, strain 28 was catalase-negative and the mechanism of resistance in this strain is unknown but could result from mutations in the promoter or regulatory gene for katG. Further studies are needed to identify the new mechanisms of INH resistance in such strains.

It is worth noting that the five INH-resistant mutants derived from type strain $\mathrm{H} 37 \mathrm{Rv}$ all had mutations in kat G, with three having the characteristic KatG Ser315Thr mutation as a result of a $\mathrm{G} \rightarrow \mathrm{C}$ change at nt 944, one having a mutation of $\mathrm{G} \rightarrow \mathrm{A}$ at nt 544 leading to Gly182Arg and one having a mutation of $\mathrm{C} \rightarrow \mathrm{T}$ at nt 148 resulting in a stop codon, with negative catalase activity and a higher MIC $\left(\mathrm{MIC}>5 \mu \mathrm{g} \mathrm{INH} \mathrm{ml}{ }^{-1}\right)$.

It is of interest to note that, of the 33 INH-resistant strains, 12 had the KatG Ser315Thr mutation and 13 had the $-15 \mathrm{C} \rightarrow \mathrm{T}$ inhA promoter mutation, accounting for $76 \%$ (25/33) of the INH-resistant strains. Although the number of strains analysed was relatively small, the findings of this study are consistent with the results of other studies such as that of Baker et al. (2005), who found that 63 and $22 \%$ of INH-resistant strains had the KatG Ser315Thr mutation and mutations in the inhA promoter, respectively. Molecular diagnostic tests based on detecting these two predominant mutations could be useful for the rapid detection of INHresistant strains.

\section{ACKNOWLEDGEMENTS}

This work was supported by NIH grants AI44063 and AI49485 and the Natural Science Foundation of China (30328031).

\section{REFERENCES}

Baker, L. V., Brown, T. J., Maxwell, O., Gibson, A. L., Fang, Z., Yates, M. D. \& Drobniewski, F. A. (2005). Molecular analysis of isoniazidresistant Mycobacterium tuberculosis isolates from England and Wales reveals the phylogenetic significance of the ahpC -46A polymorphism. Antimicrob Agents Chemother 49, 1455-1464.

Bakonyte, D., Baranauskaite, A., Cicenaite, J., Sosnovskaja, A. \& Stakenas, P. (2003). Molecular characterization of isoniazidresistant Mycobacterium tuberculosis clinical isolates in Lithuania. Antimicrob Agents Chemother 47, 2009-2011. 
Banerjee, A., Dubnau, E., Quemard, A., Balasubramanian, V., Um, K. S., Wilson, T., Collins, D., de Lisle, G. \& Jacobs, W. R., Jr (1994). inhA, a gene encoding a target for isoniazid and ethionamide in Mycobacterium tuberculosis. Science 263, 227-230.

Baulard, A. R., Betts, J. C., Engohang-Ndong, J., Quan, S., McAdams, R. A., Brennan, P. J., Locht, C. \& Besra, G. S. (2000). Activation of the pro-drug ethionamide is regulated in mycobacteria. J Biol Chem 275, 28326-28331.

Broussy, S., Coppel, Y., Nguyen, M., Bernadou, J. \& Meunier, B. (2003). $1 \mathrm{H}$ and 13C NMR characterization of hemiamidal isoniazid$\mathrm{NAD}(\mathrm{H})$ adducts as possible inhibitors of InhA reductase of Mycobacterium tuberculosis. Chemistry 9, 2034-2038.

Cole, S. T., Brosch, R., Parkhill, J. \& 39 other authors (1998). Deciphering the biology of Mycobacterium tuberculosis from the complete genome sequence. Nature 393, 537-544.

DeBarber, A. E., Mdluli, K., Bosman, M., Bekker, L. G. \& Barry, C. E., III (2000). Ethionamide activation and sensitivity in multidrugresistant Mycobacterium tuberculosis. Proc Natl Acad Sci U S A 97, 9677-9682.

Heym, B., Alzari, P. M., Honore, N. \& Cole, S. T. (1995). Missense mutations in the catalase-peroxidase gene, $k a t G$, are associated with isoniazid resistance in Mycobacterium tuberculosis. Mol Microbiol 15, 235-245.

Lee, A. S. G., Lim, I. H. K., Tang, L. L. H., Telenti, A. \& Wong, S. Y. (1999). Contribution of kasA analysis to detection of isoniazidresistant Mycobacterium tuberculosis in Singapore. Antimicrob Agents Chemother 43, 2087-2089.

Lee, A. S. G., Teo, A. S. M. \& Wong, S.-Y. (2001). Novel mutations in $n d h$ in isoniazid-resistant Mycobacterium tuberculosis isolates. Antimicrob Agents Chemother 45, 2157-2159.

Madison, B. M., Siddiqi, S. H., Heifets, L., Gross, W., Higgins, M., Warren, N., Thompson, A., Morlock, G. \& Ridderhof, J. C. (2004). Identification of a Mycobacterium tuberculosis strain with stable, lowlevel resistance to isoniazid. J Clin Microbiol 42, 1294-1295.

Mdluli, K., Slayden, R. A., Zhu, Y., Ramaswamy, S., Pan, X., Mead, D., Crane, D. D., Musser, J. M. \& Barry, C. E. (1998). Inhibition of a Mycobacterium tuberculosis $\beta$-ketoacyl ACP synthase by isoniazid. Science 280, 1607-1610.

Middlebrook, G. (1954). Isoniazid resistance and catalase activity of tubercle bacilli: a preliminary report. Am Rev Tuberc 69, 471-472.

Miesel, L., Weisbrod, T. R., Marcinkeviciene, J. A., Bittman, R. \& Jacobs, W. R, Jr (1998). NADH dehydrogenase defects confer isoniazid resistance and conditional lethality in Mycobacterium smegmatis. J Bacteriol 180, 2459-2467.

Morlock, G. P., Metchock, B., Sikes, D., Crawford, J. T. \& Cooksey, R. C. (2003). ethA, inhA, and kat $G$ loci of ethionamide-resistant clinical Mycobacterium tuberculosis isolates. Antimicrob Agents Chemother 47, 3799-3805.

Musser, J. M., Kapur, V., Williams, D. L., Kreiswirth, B. N., van Soolingen, D. \& van Embden, J. D. (1996). Characterization of the catalase-peroxidase gene $(k a t G)$ and $i n h A$ locus in isoniazid-resistant and -susceptible strains of Mycobacterium tuberculosis by automated DNA sequencing: restricted array of mutations associated with drug resistance. J Infect Dis 173, 196-202.

Ramaswamy, S. V., Reich, R., Dou, S.-J., Jasperse, L., Pan, X., Wanger, A., Quitugua, T. \& Graviss, E. A. (2003). Single nucleotide polymorphisms in genes associated with isoniazid resistance in
Mycobacterium tuberculosis. Antimicrob Agents Chemother 47, 1241-1250.

Raviglione, M. C. (2003). The TB epidemic from 1992 to 2002. Tuberculosis 83, 4-14.

Rozwarski, D. A., Grant, G. A., Barton, D. H. R., Jacobs, W. R., Jr \& Sacchettini, J. C. (1998). Modification of the NADH of the isoniazid target (InhA) from Mycobacterium tuberculosis. Science 279, 98-102.

Sajduda, A., Brzostek, A., Poplawska, M., Augustynowicz-Kopec, E., Zwolska, Z., Niemann, S., Dziadek, J. \& Hillemann, D. (2004). Molecular characterization of rifampin- and isoniazid-resistant Mycobacterium tuberculosis strains isolated in Poland. J Clin Microbiol 42, 2425-2431.

Sherman, D. R., Mdluli, K., Hickey, M. J., Arain, T. M., Morris, S. L., Barry, C. E., III \& Stover, C. K. (1996). Compensatory ahpC gene expression in isoniazid-resistant Mycobacterium tuberculosis. Science 272, 1641-1643.

Shoeb, H. A., Bowman, B. U., Jr, Ottolenghi, A. C. \& Merola, A. J. (1985). Evidence for the generation of active oxygen by isoniazid treatment of extracts of Mycobacterium tuberculosis H37Ra. Antimicrob Agents Chemother 27, 404-407.

Siddiqi, S. H. (1992). Antimicrobial susceptibility testing: radiometric (BACTEC) tests for slowly growing mycobacteria. In Clinical Microbiology Procedures Handbook, pp.14-25. Edited by H. D. Isenberg. Washington, DC: American Society for Microbiology.

Telenti, A., Honoré, N., Bernasconi, C., March, J., Ortega, A., Heym, B., Takiff, H. E. \& Cole, S. T. (1997). Genotypic assessment of isoniazid and rifampin resistance in Mycobacterium tuberculosis: a blind study at reference laboratory level. J Clin Microbiol 35, 719-723.

Vilchèze, C., Weisbrod, T. R., Chen, B., Kremer, L., Hazbón, M. H., Wang, F., Alland, D., Sacchettini, J. C. \& Jacobs, W. R., Jr (2005). Altered $\mathrm{NADH} / \mathrm{NAD}^{+}$ratio mediates coresistance to isoniazid and ethionamide in mycobacteria. Antimicrob Agents Chemother 49, 708-720.

Wengenack, N. L., Todorovic, S., Yu, L. \& Rusnak, F. (1998). Evidence for differential binding of isoniazid by Mycobacterium tuberculosis KatG and the isoniazid-resistant mutant $\mathrm{KatG}(\mathrm{S} 315 \mathrm{~T})$. Biochemistry 37, 15825-15834.

Wilson, T. M. \& Collins, D. M. (1996). ahpC, a gene involved in isoniazid resistance of the Mycobacterium tuberculosis complex. Mol Microbiol 19, 1025-1034.

Yu, S., Girotto, S., Lee, C. \& Magliozzo, R. S. (2003). Reduced affinity for isoniazid in the S315T mutant of Mycobacterium tuberculosis KatG is a key factor in antibiotic resistance. J Biol Chem 278, 14769-14775.

Zhang, Y. (2004). Isoniazid. In Tuberculosis, 2nd edn, pp. 739-758. Edited by W. N. Rom \& S. M. Garay. New York: Lippincott Williams \& Wilkins.

Zhang, Y., Heym, B., Allen, B., Young, D. \& Cole, S. (1992). The catalase-peroxidase gene and isoniazid resistance of Mycobacterium tuberculosis. Nature 358, 591-593.

Zhang, Y., Garbe, T. \& Young, D. (1993). Transformation with katG restores isoniazid-sensitivity in Mycobacterium tuberculosis isolates resistant to a range of drug concentrations. Mol Microbiol 8, 521-524.

Zhang, Y., Vilchèze, C. \& Jacobs, W. R. (2005). Mechanisms of drug resistance in Mycobacterium tuberculosis. In Tuberculosis and the Tubercle Bacillus, 2nd edn, pp. 115-140. Edited by S. T. Cole and others. Washington, DC: American Society for Microbiology. 